\title{
Suicidal deaths due to helium inhalation
}

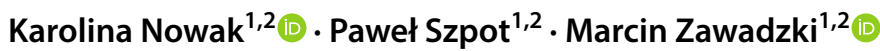

Received: 26 January 2019 / Accepted: 5 April 2019 / Published online: 7 May 2019

(c) The Author(s) 2019

\begin{abstract}
Purpose The authors reviewed the literature paying attention to helium suicide rates, autopsy findings in people exposed to helium, methods of collecting biological material for toxicological tests, and analytical methods used for detection and quantification of helium in the collected specimens.

Methods All reviewed information was gathered through a detailed search of Scopus, PubMed and the World-Wide Web using relevant keywords, e.g., helium, asphyxia, and suicide.

Results The use of helium for suicidal purposes is becoming an increasingly common phenomenon around the world. This is undoubtedly influenced by the Internet, which explains in detail the technical aspects of the suicidal use of helium and describes the dying process. Exposure to helium does not lead to poisoning; instead, death is caused by asphyxia.

Conclusions Deaths due to helium asphyxiation are still a problem for modern forensic toxicology. Most current methods for collecting biological specimens and identifying the gas seem to be insufficient to give definite opinions in cases of helium asphyxiation. More attempts should be made to modify these methods in order to improve and facilitate detection and quantitative determination of helium and other inert gases.
\end{abstract}

Keywords Helium $\cdot$ Suicide $\cdot$ Asphyxia $\cdot$ Detection and quantification $\cdot$ Sampling procedure $\cdot$ GC-MS

\section{Introduction}

Suicides still account for a considerable percentage of all deaths. There were 5276 documented suicides on the territory of Poland in 2017. Although most such deaths are the result of hanging, suicides due to poisoning by fumes or gases are not uncommon. In 2017 alone, there were 29 such deaths recorded in Poland [1]. For comparison, there were 21 documented cases in 2016, 37 cases in 2015, 18 cases in 2014, and 15 cases in 2013 [2]. Helium suicides are becoming more popular. Within 1 year, the local Forensic Medicine Department carried out five medicolegal autopsies of victims who had died due to inhalation of this gas (unpublished data). In the literature, there are reports on similar cases from other parts of this country [3-6].

Marcin Zawadzki

marcin.zawadzki@umed.wroc.pl

1 Department of Forensic Medicine, Wroclaw Medical University, 4 J. Mikulicza-Radeckiego Street, 50-345 Wrocław, Poland

2 Institute of Toxicology Research, 45 Kasztanowa Street, 55-093 Borowa, Poland
Also, the observed trend in helium suicides is not limited to Poland. In the years 2001-2011, there were 2495 suicides committed with gas $(5.2 \%$ of the total number of suicides during the study period) in England and Wales [7]. Helium suicides accounted for 183 deaths, with a noticeable upward trend from 2 cases in 2001 to 53 cases in 2011 [7]. An analysis of 1333 cases of suicide committed in the territories of Amsterdam-Amstelland and Zaanstreek-Waterland in the period from 2005 to 2014 found 83 cases of suicide by asphyxia with a plastic bag [8]. Among them, helium contributed to death in 16 cases from 2005 to 2012 and in 13 cases from 2013 to 2014 [8]. The literature also described cases reported in other European countries: Austria (three cases recorded in Vienna within 3 months) [9], Germany [10], Switzerland [11], and Norway [12].

Numerous scientific reports confirm a global upward trend in this type of death. An analysis of suicides by Forensic Science South Australia [13] over a period of 15 years (from January 2003 to December 2017) showed 33 cases of death caused by helium inhalation and 56 cases of combined nitrogen and helium poisoning. Most cases were recorded in recent years covered by the study (from 2013 to 2017). In particular, there were 15 deaths caused by helium inhalation and 
31 combined deaths [13]. It should be added that in the period from 1985 to 1999, no suicides due to helium inhalation were recorded in the territory of South Australia [14]. A review [15] of suicide cases in the USA in the years 2005-2012 showed that helium was used in 665 cases of a total of 80,715 suicides registered in the National Violent Death Reporting System (NVDRS). There were a total 3242 cases of suicidal deaths by gas asphyxiation, $73 \%$ of which were caused by carbon monoxide (CO), followed by helium (21\%) [15]. Similar results were obtained by a retrospective analysis of suicides in San Diego County between 2000 and 2012. Among 4537 suicides committed over a period of 13 years, 103 cases involved $\mathrm{CO}$ and 65 cases involved helium [16]. Also, in Hong Kong in the period from 2005 to 2013, there were 15 recorded cases of helium poisoning among a total of 8445 suicides [17]. It is worth noting an upward trend in the use of helium for suicidal purposes because 11 out of 15 cases took place in the last year covered by the study, and in the years 2005-2010, Hong Kong recorded no suicides by helium asphyxiation [17]. In the years 2000-2008, there were 10 suicides with the use of helium in North Carolina [18]. Gilson et al. [19] from the Forensic Science Center (Tucson, AZ, USA) presented cases of death due to helium asphyxiation that had occurred over a period of 18 months. Of the seven described cases, there were two collective suicides (a common-law couple and a married couple).

Asphyxiation by helium can also be used for murder. Cuypers et al. [20] presented a case of attempted extended suicide, where the mother had killed three of her children (2, 4, and 6 years old), while leaving two older offspring alive (an 11-year-old boy and a second child of unknown age). In the children's room, there were six helium cylinders connected by tubes to plastic bags. In addition to homeopathic medicines, an empty doxylamine blister pack was found at the scene. The woman was found unconscious in the bedroom. Next to her, there was a bloody syringe and empty lidocaine packaging. Before connecting the helium cylinder, the woman had given the above pharmaceuticals to the children. Toxicological tests were used to determine doxylamine in blood and urine samples for all three children. The blood concentrations of the drug in all three cases exceeded $7000 \mathrm{ng} / \mathrm{mL}$, which were lethal concentrations. Also, helium was detected from all lung specimens. The ultimate cause of death was found to be poisoning with sedatives and asphyxiation due to helium inhalation [20].

\section{Influence of mass media on helium inhalation}

The Internet plays a huge role in disseminating advice on effective suicide methods. Among others, detailed how-to instructions and instructional videos are widely available.
In a study conducted in 2014, Biddle et al. [21] showed a threefold increase in the number of "pro-suicide" websites as compared to 2007. By contrast, the number of prevention and support websites declined by half during the same period. The authors also emphasize noticeable search engine optimization of websites with how-to content and their easy accessibility [21]. A study by Gunnell et al. [22] found a strong or moderate influence of the Internet on approx. 1.5\% of suicides committed in England in 2005. In research by Tsai et al. [23], as many as $87 \%$ of survivors of attempted suicide by charcoal burning admitted that the media influenced their choice of the method for taking their life.

Website users are tempted by information about the high effectiveness of helium poisonings as well as by the fact that gas inhalation results in a quick and painless death. In addition, the Internet not only facilitates the dissemination of information about easy access to the tools necessary to commit suicide with the use of a noble gas, but also allows the purchase of the equipment such as helium cylinders [14]. In both cases described by Smędra et al. [4], the victims prepared to commit suicide using material available on the Internet. A 30-year-old man (case 1) was probably initially planning to take his own life with a gun, but later he began to collect information on alternative methods of suicide. Before he died, he had watched several instructional videos showing suicide using helium. In the second case, the man revealed in his suicide note that he had originally intended to commit suicide by hanging, cutting his veins, or overdosing on drugs, but due to insufficient skills he decided not to use these methods. The content of the letter suggested that he had found information on suicide by helium asphyxiation on the Internet. Additionally, the man decided to record his death using the webcam built into his laptop [4].

Another significant factor in the popularity of helium and other gas poisonings is numerous blogs and Internet forums that bring together people interested in euthanasia. One example is the group called Church of Euthanasia. According to Gallagher et al. [24], its members believe that the Earth is overpopulated and suicides are a "remedy" to restore the balance in nature. This is confirmed by the motto on the website: "Save the planet, kill yourself" [25]. The group advocates, among others, using helium to take one's own life. The Church of Euthanasia website (www. churchofeuthanasia.org) includes detailed instructions on self-asphyxiation with helium [24]. We should also keep in mind that some countries, such as Switzerland, have legalized euthanasia. The most popular Swiss organizations dealing with assisted dying are Exit Deutsche Schweiz (website: www.exit.ch), which advises German-speaking individuals, and Exit Association pour le Droit de Mourir dans la Dignité (Exit A.D.M.D., website: www.exit-geneve.ch), which serves French-speaking individuals, both founded in 1982 [26-28]. The services provided by Exit A.D.M.D. are 
available only to Swiss citizens [29]. Dignitas, a Zurichbased organization established in 1998, seems to be particularly popular among foreigners, including Germans and British [29]. These practices, involving performance of euthanasia abroad in countries where it is allowed, have been dubbed "suicide tourism" [28]. In the USA, the largest nongovernmental right-to-die organization is Compassion and Choices (www.compassionandchoices.org) [29, 30]. Such organizations, as well as many other around the world, provide open Internet access to, among others, materials on methods of euthanasia, including helium asphyxiation.

Information on ways of taking one's own life is also available in the form of books or films. Two popular books are Final Exit: the practicalities of a self-deliverance and assisted suicide for the dying by Derek Humphry, published in 1991 [31], and its follow-up from 2000 entitled Supplement to Final Exit: the latest how-to and why of euthanasia hastened death [32]. Although these books were intended for the incurably ill who leaned towards euthanasia, many readers were people wanting to take their lives. Already in 1994, Marzuk et al. [33] observed that the book significantly contributed to an increase in the suicide rate. The authors analyzed the statistics for suicides committed in New York after the publication of Final Exit and found an increase in deaths by plastic bag asphyxiation from 8 cases in the period of 1 year prior to the publication of the book (from 1 March 1990 until 1 March 1991) to 33 cases in the period of 12 months after the publication date (from 1 March 1991 until 28 February 1992) [33]. The first edition of Final Exit omitted the use of gases for suicidal purposes. The possibility of using helium for asphyxiation was described in Supplement to Final Exit and presented in the form of a recording, while in the third edition from 2002, the author included an entire chapter devoted to death due to gas poisoning [34]. The "usefulness" of the books in death planning is confirmed by the case described by Ogden and Wooten [35]. A 60-year-old woman committed suicide with the use of a surgical mask connected to a helium cylinder. Near the corpse there was a copy of the book Final Exit, a VHS tape entitled Final Exit: the video, and a newsletter of the Hemlock Society with an article on suicides by the use of a plastic bag and helium [35]. Ogden [34] also described the case of a 70-year-old woman suffering from myalgic encephalomyelitis who underwent euthanasia using helium. According to the author, the woman had been collecting right-to-die literature and other publications for more than 15 years, including the film The Art of Self-Deliverance from a Terminal Illness. She decided to end her life by following the steps shown in the film [34]. A copy of Final Exit was found at the scene in the second case described by Schaff et al. [36]. Right-to die literature and how-to publications were found in one of the three cases described by Grassberger and Krauskopf [9]. Similarly, Oosting et al. [37] stated that at the scene of one of the three described cases, apart from the suicide note, there was a manual on how to commit suicide with helium. In the case described by Schön and Ketterer [11], the "instructions" on committing suicide with helium or nitrogen were found at the home of the victim and not at the scene of the suicide-a rented hotel room. A rental bill discovered near the corpse confirmed the purchase of a cylinder in a balloon shop suggested in the notes [11].

\section{Properties and mechanism of action of helium}

Helium is a colorless, odorless, and non-flammable gas commonly used for filling balloons [38]. It is also used in industry and medicine, among others to treat decompression sickness [28, 39, 40]. Unlike xenon, it shows no anesthetic properties [39]. However, there has been promising research showing cardio and neuroprotective effects of helium at the cellular level. It is suggested that the use of helium in perioperative procedures could protect patients against episodes of organ ischemia [41]. It is the lightest of noble gases (molar mass $4 \mathrm{~g} / \mathrm{mol}$ ) and is characterized by the lowest melting and boiling points among all chemical elements [39]. Compared to oxygen, it has lower density $\left(0.179 \mathrm{~g} / \mathrm{m}^{3}\right)$ and absolute viscosity (201.8 $\mu$ poise). These properties determine the easier flow of helium through the lungs due to lower gas resistance (the flow depends on the viscosity and density of each element in the gas mixture) [41]. When the lungs become filled with helium, oxygen is quickly removed from them. Suicidal asphyxia with helium is additionally facilitated by a tube supplying helium to a plastic bag placed on the head. The flow of helium into the bag accelerates removal of oxygen and carbon dioxide remaining in the airways, which results in a rapid loss of consciousness [35]. Prolonged inhalation of pure helium causes hypoxia, which can easily lead to lethal hypoxic-ischemic encephalopathy [42]. It is estimated that loss of consciousness due to lack of oxygen occurs within 5-10 s, and after just 2 min, irreversible changes may occur in the brain [28]. Atmospheric air is considered to be composed of approximately $78 \%$ nitrogen and $21 \%$ oxygen. It is assumed that the first symptoms of oxygen deficiency occur at oxygen concentrations of around $12-16 \%$. The affected person experiences increased heart and breathing rates and may also exhibit slightly disturbed muscular coordination. At oxygen concentrations in the range of $10-14 \%$, the symptoms include breathing problems and easy fatigue during exercise. There is also noticeable nervousness and anxiety. When oxygen levels reach 6-10\%, nausea, fainting, and loss of consciousness may occur. At oxygen concentrations below $6 \%$, there is convulsive movement and cessation of the heart rate and respiration [28]. 
Ogden et al. [28] conducted studies of four cases of assisted suicide by oxygen deprivation using helium. The estimated time from the moment of inhalation until loss of consciousness ranged from 36 to $55 \mathrm{~s}$, with death occurring after about 5-10 min in 3 cases and after $40 \mathrm{~min}$ in the fourth case. The authors explain the outlier case by improper adjustment of the face mask and seepage of oxygen from the air into the apparatus. The oxygen concentration was sufficient to sustain basic life functions [28]. In two other cases described by Ogden [34], loss of consciousness occurred after, respectively, 10 and $12 \mathrm{~s}$ from inhalation of helium. In the first case, death occurred almost 9 min thereafter, while in the second case it occurred after just over 11 min [34].

Other complications associated with helium inhalation include the possibility of embolism due to inhalation of helium under excessive pressure. Tretjak et al. [43] described the case of a 23-year-old singer who, in order to modulate his voice, was inhaling gas from a cylinder without reducing the pressure. After a few seconds, the man lost consciousness; however, spontaneous breathing was maintained. After rapid transport to an emergency department, he gradually regained consciousness. The patient complained of chest pain (which persisted up to $24 \mathrm{~h}$ after the incident). An electrocardiogram revealed ST segment elevation (which normalized after $30 \mathrm{~min}$ ), and a chest X-ray confirmed pulmonary congestion and pneumomediastinum. Elevated troponin $\mathrm{T}$ persisted up to $6 \mathrm{~h}$, and drowsiness gradually disappeared within $10 \mathrm{~h}$. The patient was discharged after 3 days [43].

\section{External findings of the corpses and scenes reported in the literature}

Due to the fact that death by helium asphyxiation cannot be associated with any pathognomonic signs or symptoms, the only evidence supporting testing for poisoning with this gas can come from description of external examination of the corpse and the scene where it was found [14, 19]. The autopsy findings, such as pulmonary and brain edemas, internal organs congestion, or subconjunctival petechiae, are non-specific for this type of death [3]. These were confirmed by numerous cases of suicidal death by helium asphyxiation described in the literature. In Table 1, the authors listed autopsy findings and methods of helium delivery in cases of death by asphyxiation with this gas.

Although determination of gases requires a lot of efforts and work as well as modification of the method of protecting specimens for postmortem toxicological analysis, researchers tried to determine helium in specimens of internal organs, and even in peripheral blood. In a study conducted by Auwaerter et al. [10] on a volunteer who took one breath of pure helium, the authors showed that after three normal breathing cycles helium was virtually undetectable in a sample of exhaled air. The results of the research indicate that in cases of suspected poisoning by gas, including helium, it is extremely important in the diagnostic process to collect and secure toxicological specimens as quickly as possible [10]. Table 2 presents descriptions of the methods of collecting autopsy material to identify helium by chromatographic methods.

In order to investigate the exact mechanism of death due to helium inhalation, Borowska-Solonynko and Dąbkowska [6] proposed a test for air embolism of the heart. The test was carried out by puncturing the heart chambers with a syringe containing a small amount of water and then aspiring the content of the chamber. Similarly, Varlet et al. [44] considered postmortem computed tomography as a useful tool in cases of suspected deaths due to helium gas embolism.

\section{Methods of detecting helium poisonings}

Due to the physical properties of helium (gas), the only methods enabling its separation are variants of gas chromatography (GC), e.g., GC with headspace analysis. The most commonly used detectors are mass spectrometers (MSs) [3, 10, 20, 44-47] and thermal conductivity detectors (TCDs) [36-38, 48]. However, Tsujita et al. [47] pointed out the poor selectivity and sensitivity for helium detection by GCTCD. In the case of helium, the methods commonly used in clinical and forensic toxicology require modifications. Since helium is often used in gas chromatography as a carrier gas (mobile phase), its determination in gas samples necessitates a change of the mobile phase [18]. Many researchers [3, 10, $20,36,37,49]$ propose use of nitrogen as the mobile phase in cases of testing for helium. Malbranque et al. [45], Musshoff et al. [46], Varlet et al. [44], and Tsujita et al. [47] used hydrogen as the carrier gas in their analyses. Tsujita et al. [47] demonstrated that hydrogen gave the highest intensity and the good shape of helium peak as compared to argon or nitrogen as a mobile phase. It was also suggested and confirmed by Varlet et al. [44] to use hydrogen as a carrier gas to obtain the best selectivity and sensitivity of the method. According to the available literature data, volatile substances are analyzed under isothermal conditions $[3,10,20,36,37$, 44-47]. In the case of MS detection, the preferred detection mode is selected ion monitoring (SIM) [3, 10, 20, 44-47]. Table 3 shows the methods used to detect helium in autopsy specimens, and their qualitative and quantitative results. 


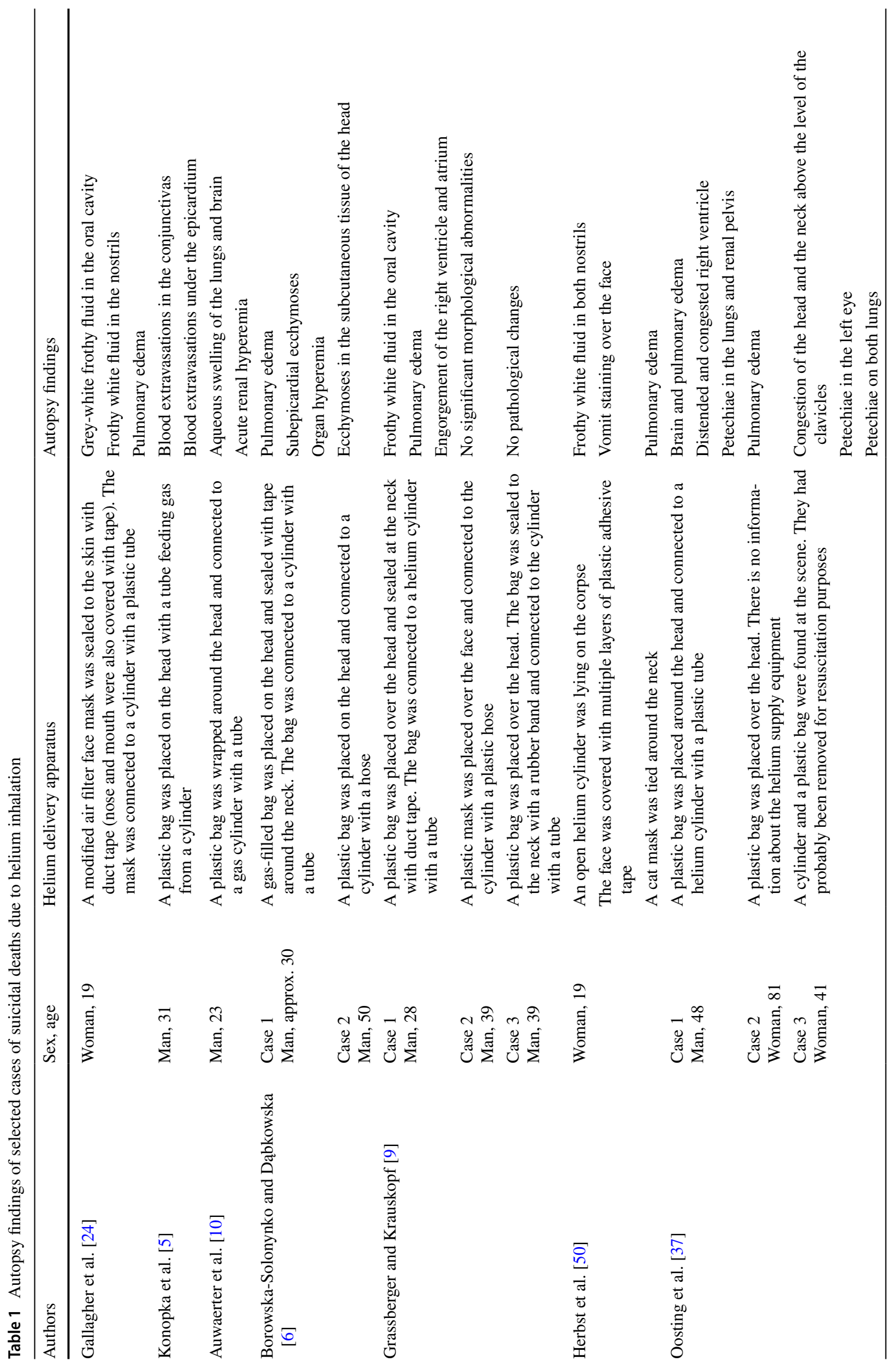




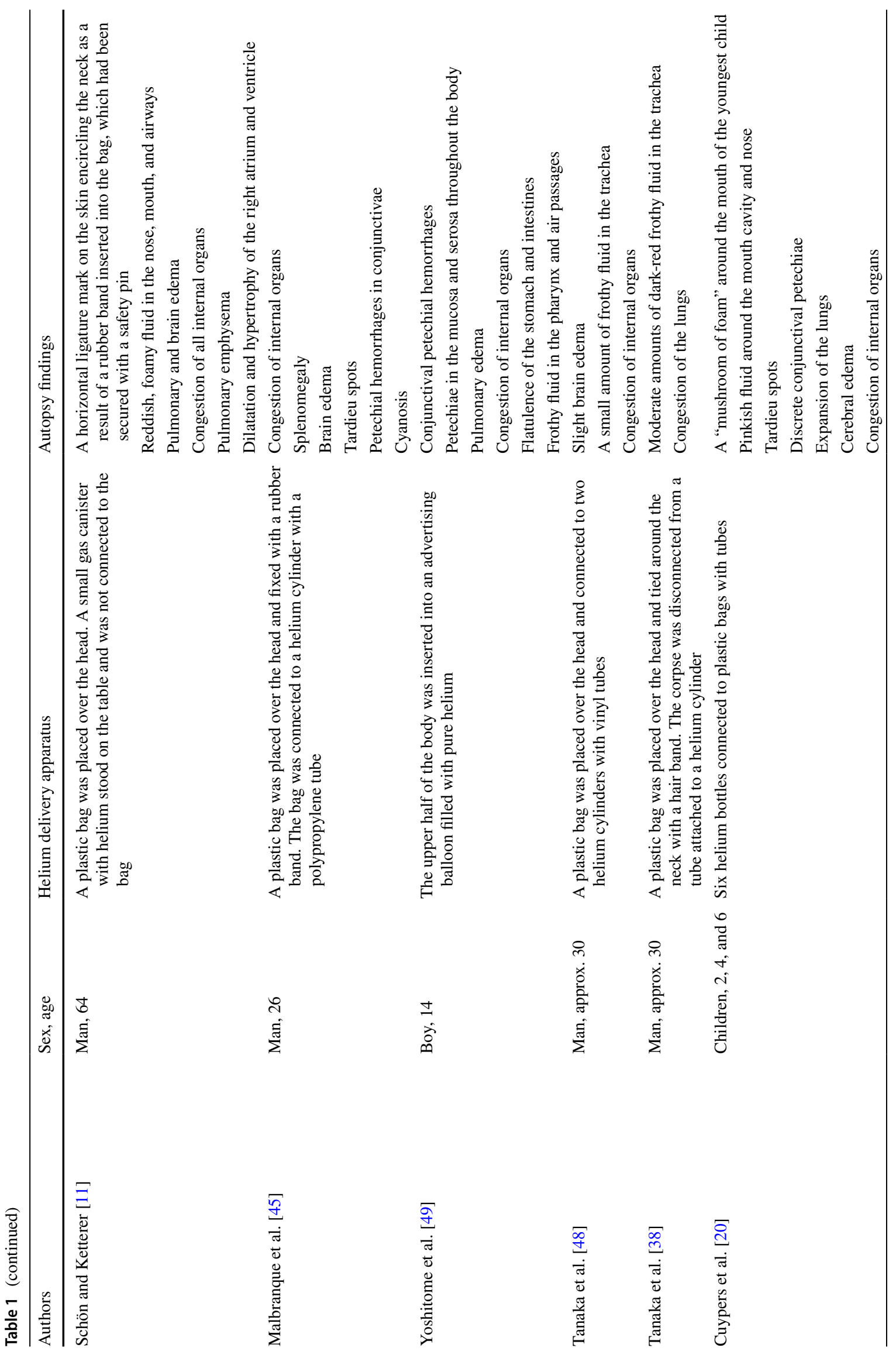




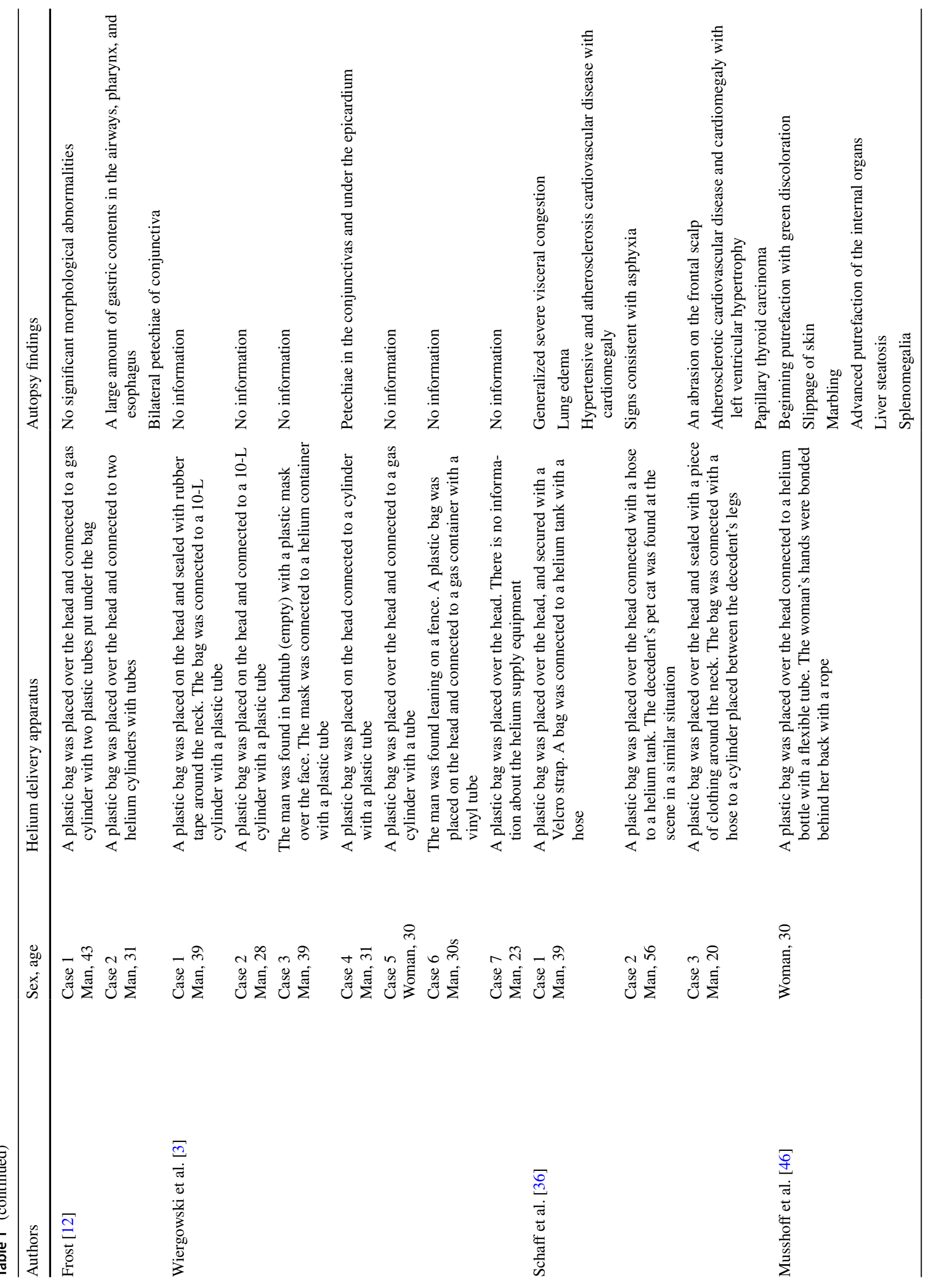


Table 2 Procedures for collecting materials for identification/quantification of helium in human specimens

\begin{tabular}{lll}
\hline Authors $\quad$ Biological specimen $\quad$ Equipment and sampling procedure \\
\hline
\end{tabular}

Auwaerter et al. [10] Lungs

Wiergowski et al. [3] Lungs

Malbranque et al. [45] Trachea

Stomach

Lungs

Peripheral blood

Musshoff et al. [46] Lungs
The lungs were placed in a plastic box with lid which was filled with water

The box was turned upside down, and residual air was sucked out with a syringe fitted with a T-piece

The lungs placed in the box were manipulated with thick metal needles

The gas from the lungs was collected via syringe

A headspace vial was filled with water and crimped before pushing the gas into the vial

A second cannula was used to displace water in the vial with gas

Variant I

The lungs were placed in a bucket full of water

The bucket was put into a tub with water (to avoid air getting inside, the bucket was placed upside down)

Residual air from the bucket was sucked out with a syringe and the hole was sealed

The lung was pressed to release gas

The gas was collected into a headspace container filled with deionized water (while gas was pumped into the vial, water was pushed out through the other opening)

Variant II

The lung was placed in a plastic bag and tightly sealed

A silicone gasket was taped around the middle of the bag and on the other side

The sealed bag was heated at $50{ }^{\circ} \mathrm{C}$ for $1 \mathrm{~h}$ on a heating plate

In the next step, the bag was manually pressed for approx. 2 min

The gas released from lung tissue was collected in the same way as in variant I (with a syringe)

The trachea was clamped

The heart and both lungs were removed from the chest cavity, and a clamp was placed on each primary bronchus

Tracheal gas was collected into a syringe and placed in a headspace vial filled with water (a second cannula was used to displace water in the vial with gas)

The vial cap was sealed with Parafilm and was kept in an inverted position

The esophagus was clamped

The esophagus and stomach were removed, and clamps were put on the duodenum and esophagus (at the level of the pylorus)

After applying pressure on the stomach, the gas was collected in the same way as from the trachea

The clamp was removed before placing each lung into an airtight container filled with water

The container was closed and turned upside down, and then it was placed into a larger container also filled with water

Residual air was sucked out with a needle connected to a three-way valve

The lid from the first container was removed before massaging the lung

The gas was aspirated through a needle and placed into a headspace vial in the same way as described above

$19.88 \mathrm{~g}$ of peripheral blood was collected into a $20-\mathrm{mL}$ headspace vial, leaving a volume of $1.33 \mathrm{~mL}$

A modification of the method described by Auwaerter et al. [10] was used

Each lung was placed into a separate container filled with water

The containers were turned upside down and placed into a basin of water

Residual air was sucked out with a syringe fitted with a T-piece

The lungs were manipulated with scissors and compressed by hand

The gas was collected with a syringe and pushed into a headspace vial filled with water (the vial cap was punctured with a second cannula to displace water while gas was pressed into the vial) 
Table 2 (continued)

\begin{tabular}{|c|c|c|}
\hline Authors & Biological specimen & Equipment and sampling procedure \\
\hline \multirow[t]{3}{*}{ Yoshitome et al. [49] } & Stomach and airways & $\begin{array}{l}\text { The gas was collected with a syringe from the stomach and airways, and injected directly } \\
\text { into a gas chromatograph }\end{array}$ \\
\hline & Lungs & A 1-cm cube-shaped lung specimen was cut and placed into a vial \\
\hline & & $\begin{array}{l}\text { The vial was plugged and heated to } 55^{\circ} \mathrm{C} \text {; then, the headspace of the vial was collected with } \\
\text { a syringe and injected into a gas chromatograph }\end{array}$ \\
\hline \multirow[t]{6}{*}{ Tanaka et al. [48] } & Trachea & $\begin{array}{l}\text { Intratracheal gas was collected during autopsy by direct puncture of the trachea with a } \\
\text { syringe }\end{array}$ \\
\hline & & The gas was immediately injected into a sealed glass vial \\
\hline & & $\begin{array}{l}\text { The vial was incubated at } 55^{\circ} \mathrm{C} \text { for } 15 \mathrm{~min} \text { and approximately } 1 \mathrm{~mL} \text { of gas was injected into } \\
\text { a gas chromatograph }\end{array}$ \\
\hline & Lungs & The solid tissue debris of each organ were collected in glass vials and sealed with screw \\
\hline & Liver & caps until analysis \\
\hline & Femoral blood & The samples were analyzed in accordance with the intratracheal gas sample \\
\hline \multirow[t]{4}{*}{ Tanaka et al. [38] } & Trachea & Sample collection and preparation was performed in accordance with [48] \\
\hline & Stomach & Stomach gas was collected by direct puncture of the wall during the autopsy \\
\hline & & $\begin{array}{l}\text { The collected gas was injected into a sealed glass vial and was incubated according to the } \\
\text { previous report [48] }\end{array}$ \\
\hline & Lungs & No information about sample collection is available \\
\hline \multirow[t]{4}{*}{ Cuypers et al. [20] } & Lungs & The procedure was performed according to Auwaerter et al. [10] \\
\hline & & In addition, lung tissue specimens were also placed into a headspace vial and sealed \\
\hline & Brain & Brain specimens were immediately stored in a vial \\
\hline & Peripheral and heart blood & Blood samples were collected in tubes with sodium fluoride \\
\hline \multirow[t]{4}{*}{ Oosting et al. [37] } & Lungs & $\begin{array}{l}\text { Approximate } 10 \mathrm{~g} \text { of each tissue was collected in a separate airtight glass jar (case } 1 \text { ) or in } \\
10 \text {-mL headspace vials and immediately sealed with a composite magnetic crimpcap with } \\
\text { a silicone/PTFE seal (cases } 2 \text { and } 3 \text { ) }\end{array}$ \\
\hline & Brain & Samples were stored at $-20^{\circ} \mathrm{C}$ until analysis \\
\hline & Heart and femoral blood & $\begin{array}{l}\text { Blood was collected in a plastic container (case } 1 \text { ) or in } 10-\mathrm{mL} \text { headspace vials and immedi- } \\
\text { ately sealed with a composite magnetic crimpcap with a silicone/PTFE seal (cases } 2 \text { and } 3 \text { ) }\end{array}$ \\
\hline & Pulmonary gas & $\begin{array}{l}\text { Gas was collected using a syringe and transferred into a PET/aluminum/EVA multilayer gas } \\
\text { sampling foil bag. The bag was temporary sealed in the autopsy room by heat-sealing }\end{array}$ \\
\hline Tsujita et al. [47] & Heart blood & $\begin{array}{l}\text { Whole blood taken from the deceased was transferred to a } 10-\mathrm{mL} \text { vacuum blood collection } \\
\text { tube containing sodium heparin, and refrigerated at } 4{ }^{\circ} \mathrm{C}\end{array}$ \\
\hline & & Prior to the analysis, the tube containing blood was stood at $25^{\circ} \mathrm{C}$ for $0.5 \mathrm{~h}$ \\
\hline \multirow[t]{4}{*}{ Schaff et al. [36] } & Blood & $\begin{array}{l}\text { Blood sample was collected in a red-top Vacutainer tube (case 1) or in a grey-top Vacutainer } \\
\text { tube (cases } 2 \text { and } 3 \text { ) }\end{array}$ \\
\hline & Liver & Liver and lung samples were collected in metal specimen cans (cases 1 and 2) \\
\hline & Lung & Liver sample was collected in a 20 -mL crimp-top vial (case 3 ) \\
\hline & Brain & $\begin{array}{l}\text { Brain sample was collected in a 20-mL crimp-top vial (cases } 1 \text { and } 3 \text { ) or in metal specimen } \\
\text { cans (case 2) }\end{array}$ \\
\hline \multirow[t]{7}{*}{ Varlet et al. [44] } & Tissue samples & $\begin{array}{l}\text { Tissues samples were taken rapidly during autopsy into } 10 \text { - or } 20-\mathrm{mL} \text { headspace vials, } \\
\text { sealed with aluminum cap, and stored in the cold }\end{array}$ \\
\hline & Gases & The procedure was performed according to Varlet et al. [51] \\
\hline & & $\begin{array}{l}\text { The gas sampling setup, consisting of needles equipped with taps in the closed position, was } \\
\text { installed in the body }\end{array}$ \\
\hline & & Syringes with luer-lock fittings were fixed on the tap \\
\hline & & $\begin{array}{l}\text { The gas was sampled as soon as the tap was opened, and then the system was removed from } \\
\text { the body }\end{array}$ \\
\hline & & $\begin{array}{l}\text { After sampling, gases were transferred to a } 20 \text {-mL headspace vials, previously filled with } \\
\text { filtered water, and stabilized in } 60^{\circ} \mathrm{C} \text { for } 4 \mathrm{~h} \text { (water was expelled by another needle which } \\
\text { was previously inserted to the vial through the septum) }\end{array}$ \\
\hline & & $\begin{array}{l}\text { Injections were performed manually: } 20 \mu \mathrm{L} \text { of internal standard }\left(\mathrm{CH}_{4} \text { or } \mathrm{N}_{2} \mathrm{O} \text { at concentra- }\right. \\
\text { tion of } 980 \mathrm{nmol} / \mathrm{mL} \text { headspace) and } 50 \mu \mathrm{L} \text { of biological sample were sampled in the same } \\
\text { syringe }\end{array}$ \\
\hline
\end{tabular}




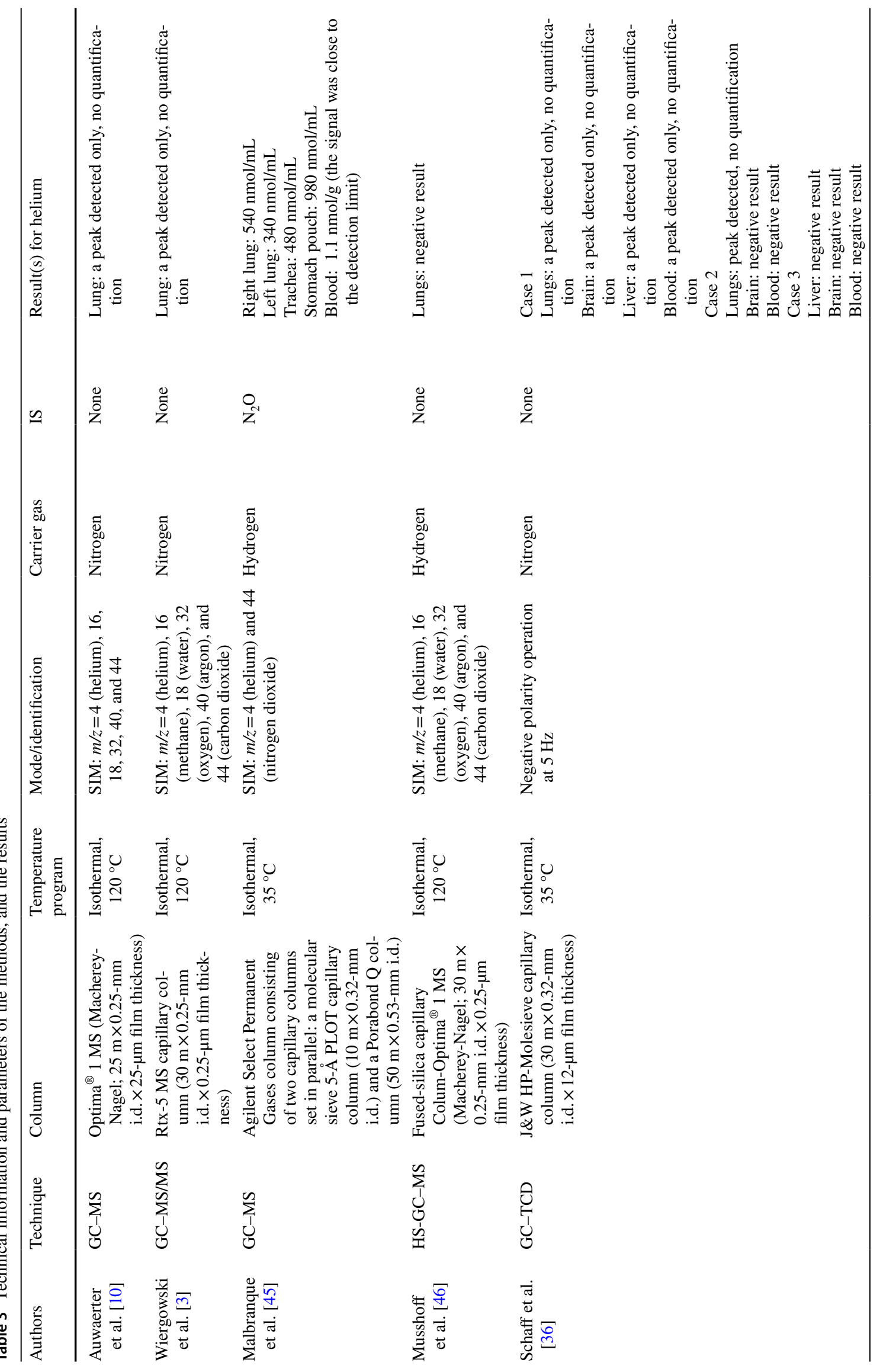




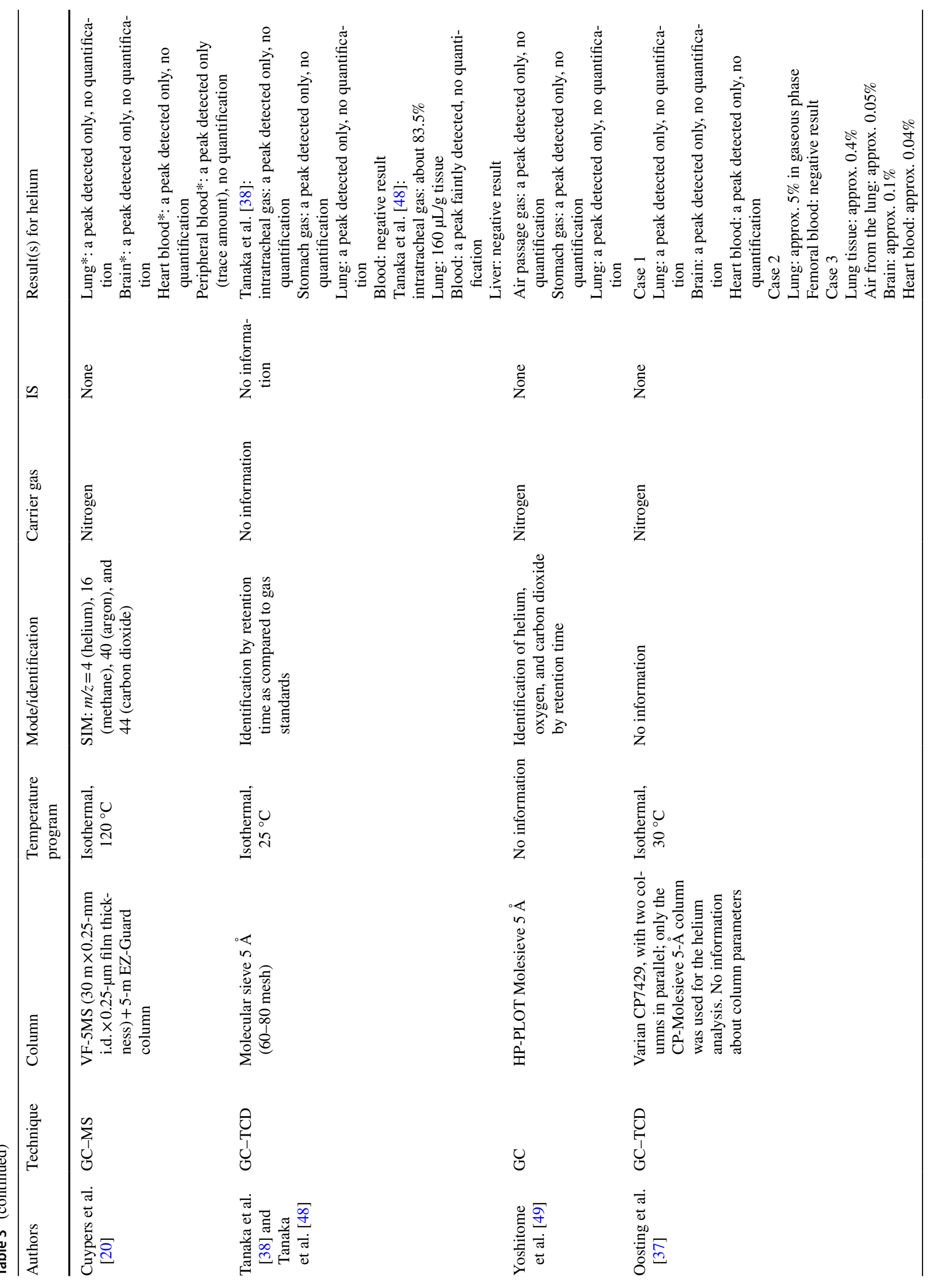




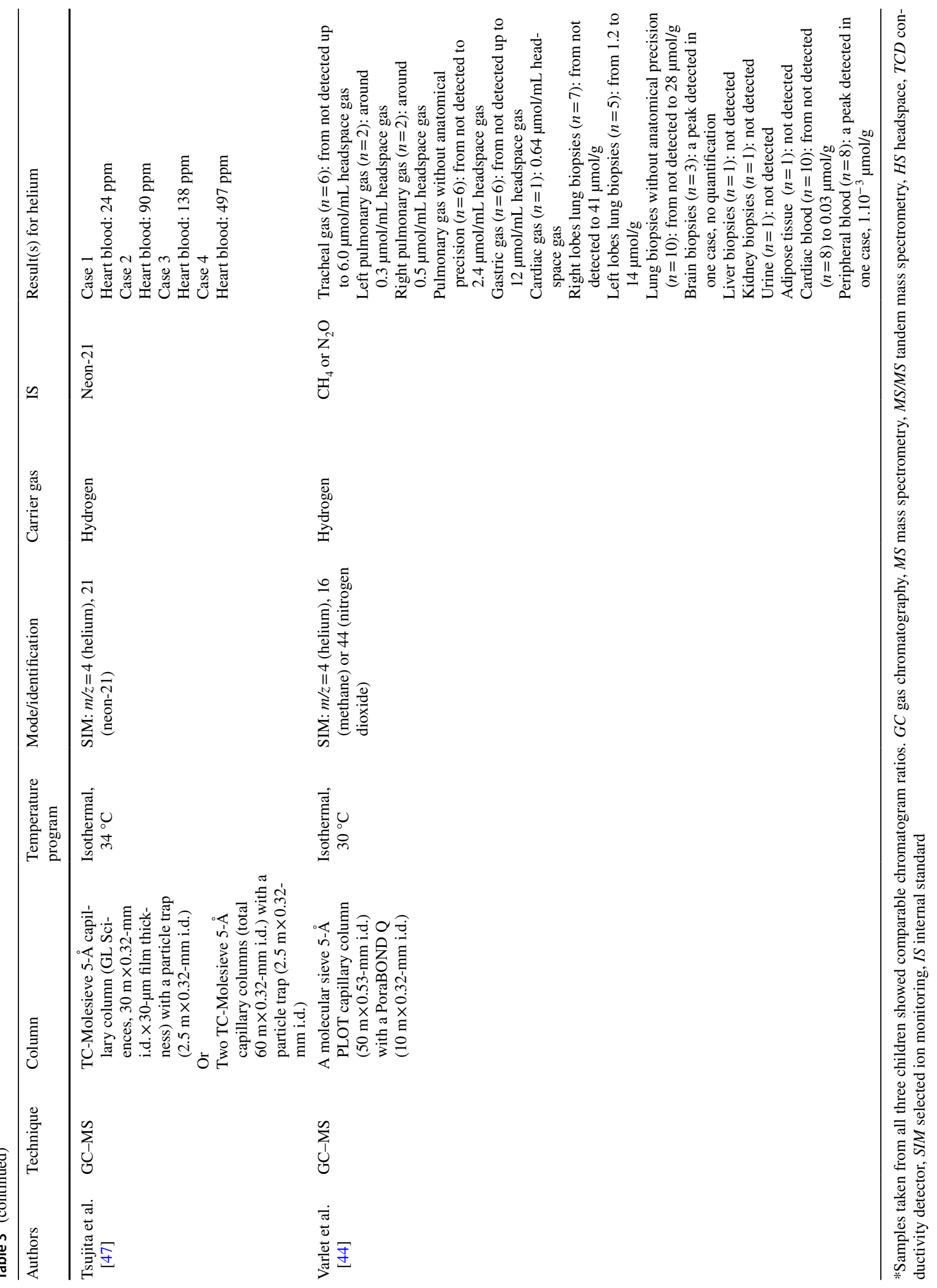




\section{Quantification of helium in human specimens}

A few scientists undertook quantitative analysis of helium or other inert gases in biological materials. Although the qualitative analysis itself is a toxicological challenge, identification of helium based only on retention time is not satisfactory or even insufficient. We should strive to develop methods for quantitative gas analysis using internal standards.

The internal standards used in determination of helium in biological material were $\mathrm{N}_{2} \mathrm{O}[44,45]$ and $\mathrm{CH}_{4}$ [44]. In addition, Tsujita et al. [47] recently proposed neon-21 as an internal standard for quantitative analysis. According to them [47], the advantage of neon-21 over other internal standards is its naturally existence in air (constant concentration at $0.049 \mathrm{ppm}$ ). Using neon-21, it is not necessary to mix an internal standard, e.g., $\mathrm{N}_{2} \mathrm{O}$ or $\mathrm{CH}_{4}$ with the gas taken from the cadaver in another headspace vial, which could cause difficulty in quantification of helium [47].

The validation parameters for helium determination and quantification, presented by Tsujita et al. [47], were: limit of detection [LOD; signal-to-noise $(\mathrm{S} / \mathrm{N})$ ratio $\geq 3$ ] of $1.8 \mathrm{ppm}$, and limit of quantification (LOQ; $\mathrm{S} / \mathrm{N} \geq 10$ ) of $6.0 \mathrm{ppm}$. Oosting et al. [37] estimated an LOD for approximately $50 \mathrm{ppm}$, but no more details were presented. There is no information about validation parameters performed by Malbranque et al. [45]. In turn, Varlet et al. [44] stated that full validation of the method was not necessary, because the analytical strategy of the research was helium screening.

Another problem in the comparative analysis of literature based on quantification of helium in biological specimens is the use of different units; e.g., Malbranque et al. [45] used $(\mathrm{nmol} / \mathrm{mL})$ for gases, and (nmol/g) for blood, Oosting et al. [37] used (\%) for pulmonary gas, tissue samples, and blood, Tanaka et al. [48] used (\%) for intratracheal gas and $(\mu \mathrm{l} / \mathrm{g})$ for lung tissue, Tsujita et al. [47] used (ppm) for quantification of helium in heart blood, and Varlet et al. [44] used ( $\mu \mathrm{mol} /$ $\mathrm{mL}$ headspace gas) for gaseous samples and $(\mu \mathrm{mol} / \mathrm{g})$ for tissue biopsies and for blood.

Equally important issue in the determination of inert gases, including helium, seems to be the selection of an appropriate biological material for conducting toxicological analyses. Varlet et al. [44] pointed out the possibility of leaks of helium from the body by passive diffusion; they [44] proposed to perform toxicological analysis, especially in lung biopsies, due to physiopathology of helium, but they also pointed out that a single lung biopsy cannot be representative of the whole organ. For this reason, many other scientists have performed analyses of lung samples in cases of suspected helium asphyxiation $[3,10,20$, 36-38, 44-46, 48, 49]. However, from an analytical point of view, gaseous samples taken from cadavers are also useful and informative specimens for quantification of helium. Some research groups [37, 38, 44, 45, 48, 49] performed analyses especially in intratracheal and pulmonary gases, which are characterized by high homogeneity. Helium can be also deposited in gastric gas, through antemortem choking or postmortem diffusion. Therefore, stomach gas could be an alternative specimen in toxicological analyses [44, 45, 49]. Cardiac gas can be also taken into account [44].

According to the literature, besides lung samples, in qualification and/or quantification of helium, blood (heart, peripheral), brain, liver, kidney, and adipose specimens were used [20, 36-38, 44, 45, 47, 48]. Their importance in determining helium in cases of suspected gas asphyxiation seems much less than lung samples. Varlet et al. [44] negated the use of kidney, liver, adipose and urine samples in toxicological analyses, because of trace amounts of helium penetrating them postmortem by passive diffusion. Scientists should not exclude performing analyses in brain specimens, where due to high vascularization, helium can be deposited. It is also worth taking into consideration of heart blood tests, especially if, due to the putrefaction changes, air passage gases are unavailable. On the other hand, Varlet et al. [44] negatively evaluated the usefulness of peripheral blood, because of trace amounts of helium due to the insufficient time for gas exchange after helium inhalation.

To sum up, Varlet et al. [44] suggested the following algorithm for helium analyses in biological samples in cases of suspected fatal helium exposure:

1. Lung biopsy analysis;

2. Tracheal and pulmonary gas analysis;

3. Gastric gas analysis;

4. Cardiac gas analysis;

5. Brain and heart gas analysis;

6. Whole lung lobe analysis.

\section{Conclusions}

Deaths due to helium asphyxiation are still a problem for modern forensic toxicology. In many cases, diagnosis of the cause of death is based on external examination of the body and a description of the scene of the incident. Most current methods of collecting and identifying helium gas in biological specimens seem to be insufficient to give definite opinions in cases of helium asphyxiation. With each subsequent analyzed case, more attempts should be made to modify these methods in order to improve and facilitate quantification of helium and other inert gases in human specimens. 


\section{Compliance with ethical standards}

Conflict of interest The authors declare that they have no conflict of interest.

Ethical statement This article does not contain any studies with human participants or animals performed by any of the authors.

Open Access This article is distributed under the terms of the Creative Commons Attribution 4.0 International License (http://creativeco mmons.org/licenses/by/4.0/), which permits unrestricted use, distribution, and reproduction in any medium, provided you give appropriate credit to the original author(s) and the source, provide a link to the Creative Commons license, and indicate if changes were made.

\section{References}

1. Zamachy samobójcze od 2017 roku. http://www.statystyka.polic ja.pl/st/wybrane-statystyki/zamachy-samobojcze/63803,Zamachysamobojcze-od-2017-roku.html. Accessed 10 Jan 2019 (in Polish)

2. Zamachy samobójcze-od 2013 do 2016 . http://www.statystyka .policja.pl/st/wybrane-statystyki/zamachy-samobojcze/12232 4,Zamachy-samobojcze-od-2013-do-2016.html. Accessed 10 Jan 2019 (in Polish)

3. Wiergowski M, Kaliszan M, Sumińska-Ziemann B, Gos T, Jankowski Z (2014) Helium detection in the lungs in case of suicide by helium inhalation - case report and literature review. Rom J Leg Med 22:153-156. https://doi.org/10.4323/rjlm.2014.153

4. Smędra A, Szustowski S, Jurczyk AP, Klemm J, Szram S, Berent J (2015) Suicidal asphyxiation by using helium-two case reports. Arch Med Sad Kryminol 65:37-46. https://doi.org/10.5114/amsik .2015 .51605

5. Konopka T, Strona M, Księżniak-Baran D, Wojton D (2013) Plastic bag suffocation in material collected by Department of Forensic Medicine in Krakow. Arch Med Sad Kryminol 63:93-98. https://doi.org/10.5114/amsik.2013.46112 (in Polish)

6. Borowska-Solonynko A, Dąbkowska A (2018) Gas embolism as a potential cause of death by helium poisoning-postmortem computed tomography changes in two cases of suicidal helium inhalation. Leg Med 31:59-65. https://doi.org/10.1016/j.legal med.2018.01.001

7. Gunnell D, Coope C, Fearn V, Wells C, Chang S-S, Hawton K, Kapur N (2015) Suicide by gases in England and Wales 2001-2011: evidence of the emergence of new methods of suicide. J Affect Disord 170:190-195. https://doi.org/10.1016/j. jad.2014.08.055

8. Van den Hondel KE, Buster M, Reijnders UJL (2016) Suicide by asphyxiation with or without helium inhalation in the region of Amsterdam (2005-2014). J Forensic Led Med 44:24-26. https:// doi.org/10.1016/j.jflm.2016.08.012

9. Grassberger M, Krauskopf A (2007) Suicidal asphyxiation with helium: report of three cases. Wien Klin Wochenschr 119:323 325. https://doi.org/10.1007/s00508-007-0785-4

10. Auwaerter V, Grosse Perdekamp M, Kempf J, Schmidt U, Weinmann W, Pollak S (2007) Toxicological analysis after asphyxial suicide with helium and a plastic bag. Forensic Sci Int 170:139141. https://doi.org/10.1016/j.forsciint.2007.03.027

11. Schön CA, Ketterer T (2007) Asphyxial suicide by inhalation of helium inside a plastic bag. Am J Forensic Med Pathol 28:364367. https://doi.org/10.1097/PAF.0b013e31815b4c69

12. Frost J (2013) Death by self-inflicted asphyxia with helium-first case reports from Norway and review of the literature. Scand J Forensic Sci 19:52-54. https://doi.org/10.2478/sjfs-2013-0010
13. Byard RW (2018) Changing trends in suicides using helium or nitrogen-a 15-year study. J Forensic Leg Med 58:6-8. https:// doi.org/10.1016/j.jflm.2018.04.007

14. Byard RW (2017) Further observations on plastic bag asphyxia using helium gas. Aust J Forensic Sci 49:483-486. https://doi. org/10.1080/00450618.2016.1177594

15. Azrael D, Mukamal A, Cohen AP, Gunnell D, Barber C, Miller $M$ (2016) Identifying and tracking gas suicides in the US using national violent death reporting system, 2005-2012. Am J Prev Med 51:219-225. https://doi.org/10.1016/j.amepre.2016.08.006

16. Cantrell L, Lucas J (2014) Suicide by non-pharmaceutical poisons in San Diego county. Clin Toxicol 52:171-175. https://doi. org/10.3109/15563650.2014.888734

17. Chang SS, Cheng Q, Lee ES, Yip PS (2016) Suicide by gassing in Hong Kong 2005-2013: emerging trends and characteristics of suicide by helium inhalation. J Affect Disord 192:162-166. https ://doi.org/10.1016/j.jad.2015.12.026

18. Howard MO, Hall MT, Edwards JD, Vaughn MG, Perron BE, Winecker RE (2011) Suicide by asphyxiation due to helium inhalation. Am J Forensic Med Pathol 32:61-70. https://doi. org/10.1097/paf.0b013e3181ed7a2d

19. Gilson T, Parks BO, Porterfield CM (2003) Suicide with inert gases: addendum to Final Exit. Am J Forensic Med Pathol 24:306-308. https://doi.org/10.1097/01.paf.0000083363.24591.5d

20. Cuypers E, Rosier E, Loix S, Develter W, Van Den Bogaert W, Wuestenbergs J, Van de Voorde W, Tytgat J (2017) Medical findings and toxicological analysis in infant death by balloon gas asphyxia: a case report. J Anal Toxicol 41:347-349. https://doi. org/10.1093/jat/bkx006

21. Biddle L, Derges J, Mars B, Heron J, Donovan JL, Potokar J, Piper M, Wyllie C, Gunnell D (2016) Suicide and the Internet: changes in the accessibility of suicide-related information between 2007 and 2014. J Affect Disord 190:370-375. https://doi.org/10.1016/j. jad.2015.10.028

22. Gunnell D, Bennewith O, Kapur N, Simkin S, Cooper J, Hawton $\mathrm{K}$ (2012) The use of the Internet by people who die by suicide in England: a cross sectional study. J Affect Disord 141:480-483. https://doi.org/10.1016/j.jad.2012.04.015

23. Tsai CW, Gunnell D, Chou YH, Kuo CJ, Lee MB, Chen YY (2011) Why do people choose charcoal burning as a method of suicide? An interview based study of survivors in Taiwan. J Affect Disord 131:402-407. https://doi.org/10.1016/j.jad.2010.12.013

24. Gallagher KE, Smith DM, Mellen PF (2003) Suicidal asphyxiation by using pure helium gas. Case report, review and discussion of the influence of the Internet. Am J Forensic Med Pathol 24:361-363. https://doi.org/10.1097/01.paf.0000097856.31249.ac

25. The Church of Euthanasia. http://www.churchofeuthanasia.org. Accessed 10 Jan 2019

26. Exit Deutsche Schweiz. http://www.exit.ch. Accessed 10 Jan 2019

27. Exit Association pour le Droit de Mourir dans la Dignité. http:// www.exit-geneve.ch. Accessed 10 Jan 2019

28. Ogden RD, Hailton WK, Whitcher C (2010) Assisted suicide by oxygen deprivation with helium at a Swiss right-to-die organisation. J Med Ethics 36:174-179. https://doi.org/10.1136/ jme.2009.032490

29. Ziegler S, Bosshard G (2007) Role of non-governmental organisations in physician assisted suicide. BMJ 334:295-298. https://doi. org/10.1136/bmj.39100.417072.BE

30. Compassion and choices. http://www.compassionandchoices.org. Accessed 10 Jan 2019

31. Humphry D (1991) Final Exit: the practicalities of self-deliverance and assisted suicide for the dying. Hemlock Soc, Eugene

32. Humphry D (2000) Supplement to Final Exit: the latest how-to and why of euthanasia hastened death. Norris Lane Press, Eugene

33. Marzuk PM, Tardiff K, Hirsch CS, Leon AC, Stajic M, Hartwell N, Portera L (1993) Increase in suicide by asphyxiation in 
New York city after the publication of Final Exit. N Engl J Med 329:1508-1510. https://doi.org/10.1056/NEJM199311113292022

34. Ogden RD (2010) Observation of two suicides by helium inhalation in a prefilled environment. Am J Forensic Med Pathol 31:151-161. https://doi.org/10.1097/PAF.0b013e3181d749d7

35. Ogden RD, Wooten RH (2002) Asphyxial suicide with helium and a plastic bag. Am J Forensic Med Pathol 23:234-237. https://doi. org/10.1097/01.PAF.0000022963.33157.9B

36. Schaff JE, Karas RP, Marinetti L (2012) A gas chromatographythermal conductivity detection method for helium detection in postmortem blood and tissue specimens. J Anal Toxicol 36:112115. https://doi.org/10.1093/jat/bks002

37. Oosting R, van der Hulst R, Peschier L, Verschraagen M (2015) Toxicological findings in three cases of suicidal asphyxiation with helium. Forensic Sci Int 256:38-41. https://doi.org/10.1016/j.forsc iint.2015.06.028

38. Tanaka N, Takakura A, Jamal M, Kumihashi M, Ito A, Ishimoto S, Tsutsui K, Kimura S, Ameno K, Kinoshita H (2016) Stomach gas as a useful matrix for detecting ante-mortem gas exposure. A case of asphyxia by helium inhalation. Rom J Leg Med 24:21-22. https://doi.org/10.4323/rjlm.2016.21

39. Berganza CJ, Zhang JH (2013) The role of helium gas in medicine. Med Gas Res 3:18. https://doi.org/10.1186/2045-9912-3-18

40. Kłos R (2007) Some problems of decompression schedule selection. Pol Hyperb Res 18:33-76 (in Polish with English abstract)

41. Oei GT, Weber NC, Hollmann MW, Preckel B (2010) Cellular effects of helium in different organs. Anesthesiology 112:15031510. https://doi.org/10.1097/ALN.0b013e3181d9cb5e

42. Singh S, Mahdi SNM (2018) Helium gas inhalation as a suicide technique. Malays J Med Health Sci 14:65-67

43. Tretjak M, Gorjup V, Mozina H, Horvat M, Noc M (2002) Cerebral and coronary gas embolism from the inhalation of pressurized helium. Crit Care Med 30:1156-1157. https://doi. org/10.1097/00003246-200205000-00034

44. Varlet V, Iwersen-Bergmann S, Alexandre M, Cordes O, Wunder C, Holz F, Andersen-Streichert H, Bevalot F, Dumestre-Toulet V, Malbranque S, Fracasso T, Grabherr S (2019) Helium poisoning: new procedure for sampling and analysis. Int J Legal Med. https ://doi.org/10.1007/s00414-019-02014-3 (ahead of print)
45. Malbranque S, Mauillon D, Turcant A, Rouge-maillart C, Mangin P, Varlet V (2016) Quantification of fatal helium exposure following self-administration. Int J Legal Med 130:1535-1539. https:// doi.org/10.1007/s00414-016-1364-X

46. Musshoff F, Hagemeier L, Kirschbaum K, Madea B (2012) Two cases of suicide by asphyxiation due to helium and argon. Forensic Sci Int 223:e27-e30. https://doi.org/10.1016/j.forsc iint.2012.08.049

47. Tsujita A, Okazaki H, Nagasaka A, Gohda A, Matsumoto M, Matsui T (2019) A new sensitive method for quantitative determination of helium in human blood by gas chromatography-mass spectrometry using naturally existing neon- 21 as internal standard. Forensic Toxicol 37:75-81. https://doi.org/10.1007/s1141 9-018-0437-6

48. Tanaka N, Kinoshita H, Jamal M, Kumihashi M, Tobiume T, Tsutsui K, Ameno K (2013) Usefulness of intratracheal gas analysis in an autopsy case of helium inhalation. Rom J Leg Med 21:237238. https://doi.org/10.4323/rjlm.2013.237

49. Yoshitome K, Ishikawa T, Inagaki S, Yamamoto Y, Miyaishi S, Ishizu H (2002) A case of suffocation by an advertising balloon filled with pure helium gas. Acta Med Okayama 56:53-55. https ://doi.org/10.18926/AMO/31726

50. Herbst J, Stanley W, Byard RW (2014) Autopsy reenactment-a useful technique in the evaluation of adhesive tape asphyxia. J Forensic Sci 59:841-843. https://doi. org/10.1111/1556-4029.12378

51. Varlet V, Smith F, Giuliani N, Egger C, Rinaldi A, Dominguez A, Chevallier C, Bruguier C, Augsburger M, Mangin P, Grabherr $S$ (2015) When gas analysis assists with postmortem imaging to diagnose causes of death. Forensic Sci Int 251:1-10. https://doi. org/10.1016/j.forsciint.2015.03.010

Publisher's Note Springer Nature remains neutral with regard to jurisdictional claims in published maps and institutional affiliations. 